\title{
Pemodelan Analisis Sentimen Masyarakat terhadap Adaptasi Kebiasaan Baru (AKB) mengunakan Algoritma Naïve Bayes
}

\author{
SITI YULIYANTI, SITI SHOLIHAH
}

\author{
Program Studi Sistem Informasi, STMIK Bandung \\ Email: sitiyuliyanti@stmik-bandung.ac.id
}

Received 6 Juli 2021 | Revised 21 Juli 2021 | Accepted 18 November 2021

\begin{abstract}
Abstrak
Pandemi Covid-19 hampir masuk tahun ke dua di Indonesia, pemerintah terus berupaya menekan laju peningkatan penularan Covid-19 melalui berbagai media. Sosialisasi dan informasi melalui media sosial yang merupakan wadah paling cepat untuk tersampaikan kepada masyarakat. Berbagai istilah digunakan seperti adaptasi kebiasaan baru, social distancing, PSBB sampai PPKM sehingga memicu masyarakat untuk beropini di media sosial. Penelitian ini menganalisis sentiment masyarakat terkait opini peningkatan Covid-19 dari twitter. Klasifikasi tweet menggunakan Naive Bayes dengan penambahan seleksi fitur. Penggunaan confusion matriks untuk mengetahui performance algoritma Naive Bayes. Berdasarkan pengujian, penelitian ini menghasilkan $76 \%$ dengan accuracy positif sebesar 72,727\%, accuracy negatif sebesar 75\% dan accuracy netral sebesar 78,947\%. Sehingga disimpulkan penggunaan model klasifikasi Naive Bayes dengan fitur seleksi dapat meningkatkan akurasi.
\end{abstract}

Kata kunci: analisis sentimen, seleksi fitur, twitter crawling, naïve bayes, klasifikasi, emosi

\begin{abstract}
Covid-19 pandemic is almost in its second year in Indonesia, the government continues to try to suppress the rate of increase in the transmission of Covid-19 through various media. Socialization and information through social media which is the fastest medium to be conveyed to the public. Various terms are used, such as adapting new habits, social distancing, PSBB to PPKM, thus triggering the public to share opinions on social media. This study analyzes public sentiment regarding the increasing opinion of Covid-19 from twitter. Tweet classification based on positive, negative and neutral classes using Naive Bayes with feature selection. The use of confusion matrix to determine the performance of the Naive Bayes algorithm. BasedThis Research, the results from the sentiment analysis system using the nave Bayes classifier of $76 \%$ with positive accuracy of $72.727 \%$, negative accuracy of $75 \%$ and neutral accuracy of $78.947 \%$. So it can be concluded that the use of the Naive Bayes classification model with the selection feature can increase accuracy.
\end{abstract}

Keywords: sentiment analysis, fitur selection twitter crawling, naïve bayes, clasification,

emotion 


\section{PENDAHULUAN}

Pandemi yang disebabkan virus Covid-19 melanda berbagai Negara tak terkecuali Indonesia, sehingga penerapan berbagai kebijakan untuk mengurangi menyebarnya covid-19. Berbagai istilah muncul seperti Social Distancing, adaptasi kebiasaaan baru atau new normal, termasuk PSBB (Pembatasan Sosial Berskala Besar) atau saat ini dikenal dengan PPKM. Namun ada beberapa sector yang tidak bias lepas dari rutinitas sehingga harus memulai beradapatasi dengan pemakaian masker, penggunaan handsanitizer atau penyemprotan berkala dengan disinfektan. Hal tersebut membuat banyak opini atau sentiment dari berbagai kalangan yang dituangkan diberbagai media social. Penelitian ini mengangkat objek tentang evaluasi algoritma yang digunakan untuk mengklasifikasikan sentiment masyarakat terhadap adaptasi kebiasaan baru atau new normal yang ramai diperbincangkan di mesia sosial.

Analsisis sentiment dapat dimaknai langkah pemberian kelas dalam tingkatan emosi yang dapat tertuang pada cuitan di media sosial (Mubaroka, Adiwijayab, \& Aldhi, 2017). Beragam opini engguna media social terkait kasus Covid-19. Sosial media menjadi wadah untuk melampiaskan perasaan di kalangan masyarakat, salah satunya pengguna media social. Sebuah sarana didunia masya yaitu cuitan pada Twitter men-trigger beredarnya informasi mengenai hal apapun termasuk pandemi yang disebabkan covid-19. Terkadang cuitan yang menjadi viral dapat menyebabkan pengungkapan makna yang kompleks (Hermanto \& Noviriandini, 2021). Implementasi analisis sentiment berupa cuitan dalam twitter dapat menimbulkan beragam persepsi atau opini terhadap topik yang di tulis (Yuliyanti, Djatna, \& Sukoco, 2017). Cuitan (tweet) yang berasal dari twitter tidak memiliki interferensi dan berisi banyak kesalahan (noise), sehingga diperlukan aplikasi atau sistem untuk memperoleh makna atau nilai yang terkandung dalam sebuah kalimat, penelitian tentang analisis dokumen tekstual paling tinggi akurasinya menggunakan metode Naïve Bayes dimana performance algoritma bergantung dari jumlah data. Klasifikasi yang baik dimana hasill akurasi menunjukan tingkat yang semakin tinggi (Ratino, Hafidz, Anggraeni, \& Gata, 2020).

Naive Bayes Classifier (NBC) adalah yang paling sering digunakan karena algoritma ini sangat cocok untuk short dan text. Algoritma Naïve Bayes Classifier (NBC) menghitung probabilitas eksplisit untuk hipotesis dan kuat untuk kebisingan (noise) dalam input data. Secara statistik pengklasifikasi Bayes meminimalkan kemungkinan kesalahan klasifikasi (Larose, 2014). Naive Bayes classifier menggunakan prior probability (yaitu nilai probabilitas yang diyakini benar sebelum melakukan eksperimen) dari setiap label yang merupakan frekuensi masing-masing label pada training set dan kontribusi dari masingmasing fitur (Ratnawati, 2018). Performa algoritma klasifikasi dapat ditingkatkan dengan proses feature selection dengan tujuan mereduksi atribut- atribut yang tidak seesuai dengan kategoorinya sehingga akurasi menjadi lebih baik. Feature Selection yang digunakan dalam penelitian ini adalah Term Frequency-Inverse Document Frequency (TF-IDF), algoritma ini diimplementasikan untuk menentukan seberapa penting sebuah kata untuk dokumen relatif terhadap corpus. Penelitian ini akan menguraikan evaluasi pemodelan klasifikasi sentimen pengguna twitter terhadap adaptasi kebiasaan baru atau lebih dikenal dengan istilah new normal dengan algoritma Naive Bayes sehingga diperoleh seberapa akurat algoritma Naïve Bayes yang digunakan sebagai teknik pengklasifikasian pada data yang berasal dari twitter dengan jumlah yang besar. Pengujian untuk mengevaluasi model klasifikasi menggunakan confusion matriks dengan parameter yang dihitung yaitu accuration, precision, recall untuk setiap kelas yang dihasilkan oleh model. 


\section{METODE PENELITIAN}

Tahapan penelitian meliputi pengumpulan data cuitan (crawling) dan labelling, text processing, pembobotan term, pemodelan dan evaluasi model sebagaimana kerangka penelitian diilustrasikan Gambar 1.

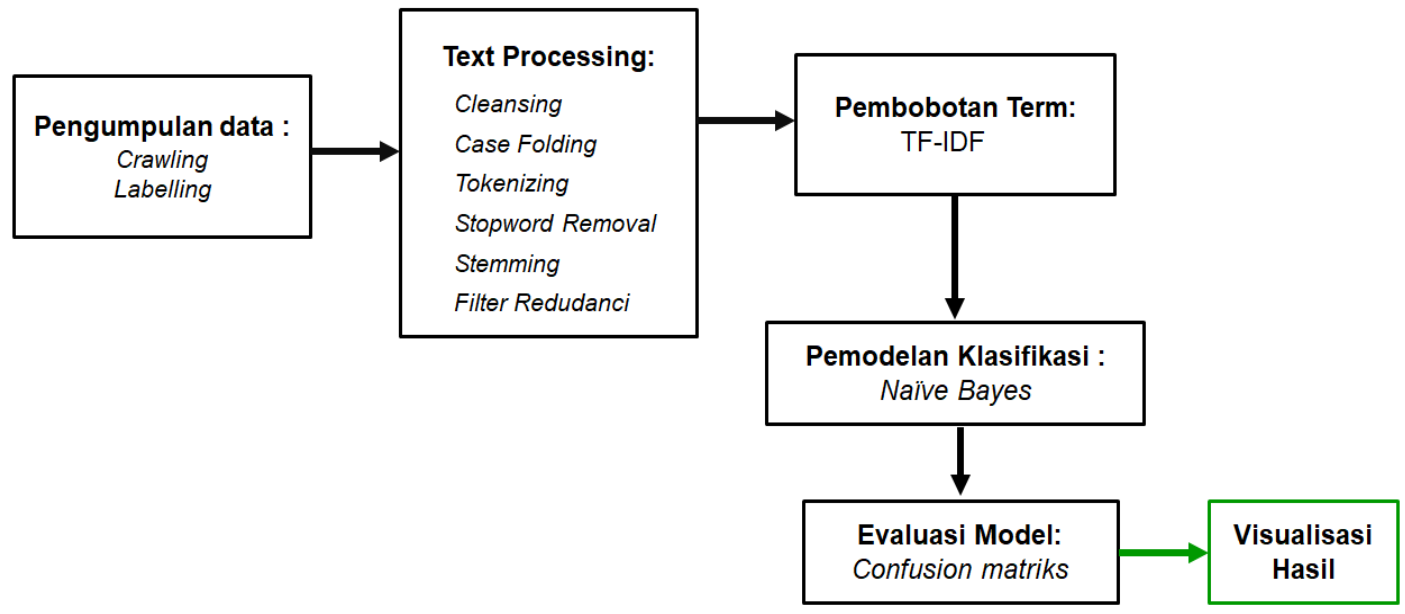

\section{Gambar 1. Kerangka Penelitian}

Proses mengambil data dari media sosial Twitter untuk pengumpulan dataset lebih dikenal dengan nama crawling. Pegumpulan data penelitian ini mengangkat objek tweet dari Twitter yang mengandung pembahasan tentang "COVID-19", "PSBB", "Adaptasi Kebiasaan Baru", "New Normal" yang dicrawling sebanyak 10.000 tweet. Penelitian ini menggunakan API Standard V1.1 dengan tingkat akses hingga 400 kata kunci, dengan batasan 15 permintaan per detik untuk setiap pengguna, semua jendela permintaan dibatasi per 15 menit. Penelitian ini mengambil data set berdasarkan tweet dari region Indonesia dan berbahasa Indonesia yang kemudian diberi label positif, negatif dan netral. Tahapan pengumpulan data diilustrasikan pada Gambar 2.

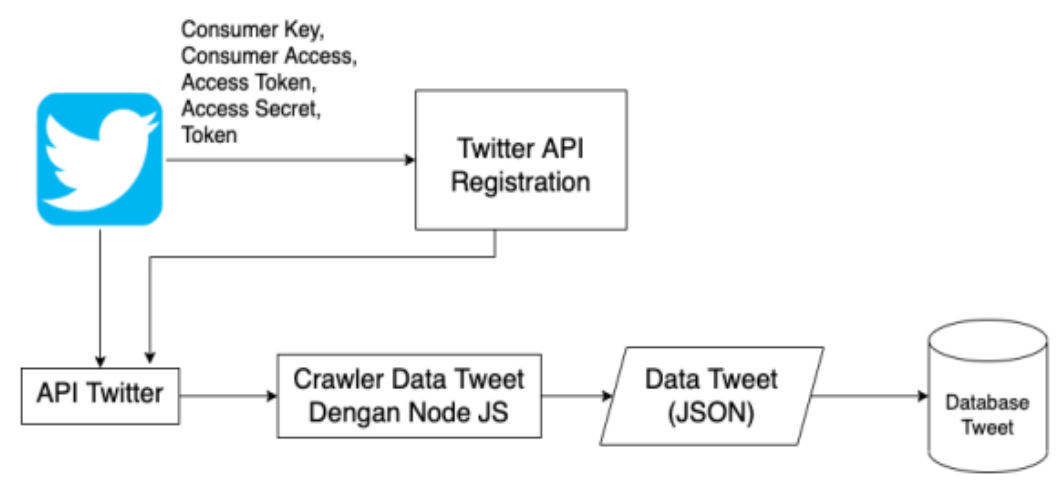

Gambar 2. Flowchart crawling data tweet

Dataset tweet dari hasil crawling dipecah pada data training dan data testing. Kemudian diberi label secara manual terlebih dahulu dengan memberikan label positif, negatif atau netral pada setiap tweet. Selain mengumpulkan data training secara masal, dapat pula 
dilakukan proses input data training berupa single tweet pada form training data dalam sistem. Data training disimpan dalam dataset json agar dapat dipanggil kembali (recall) oleh system. Data testing dari hasil crawling disimpan untuk diolah ke dalam sistem sehingga output secara otomatis tampil berupa kelas sentiment.

Tahapan text processing meliputi case folding, tokenizing, stopword removal, stemming. Pembobotan term, penelitian ini menggunakan TF-IDF, pemodelan dilakukan dengan mengimplementasikan Naïve Bayes Classifier sedangkan evaluasi model menggunakan confusion matriks dan divisualisasikan dnegan grafik. Tahapan text processing dimulai dengan cleansing untuk mengurangi noise dilakukan proses pembersihan. Kata yang dihilangkan dapat berupa karakter dari script $\mathrm{HTML}$, kata kunci, emoticon, hashtag (\#), username dan URL. Noise dapat mengganggu proses penilaian analisa sentiment. Selanjutnya dilakukan case folding, yang merupakan pengubahan semua huruf yang terdapat dalam dokumen menjadi huruf kecil atau lowercase dan menghilangkan karakter selain huruf. Selanjutnya dilakukan proses tokenizing, dimana pada proses ini dilakukan pemotongan atau pemisahan setiap kata yang terdapat dalam kalimat berdasarkan pemisah kata seperti spasi, koma (,) dan titik (.) (Yuliyanti \& Rizky, 2020). Bagian yang hanya memiliki satu karakter non alfabet dan angka dibuang, sehingga menghasilkan kata-kata dalam array. Kemudian tahapan stopword removal dilakukan, dimana semua kosakata yang tidak memiliki makna dihilangkan dari dalam dokumen sehingga menyisakan kata yang bermakna saja di dalam dokumen. Sebelum proses stopword removal harus dibuat daftar stopword list. Yang termasuk ke dalam daftar ini misalnya "oleh", "pada", "di", "sebuah", "karena" dan lain-lain. Jika ada kata yang termasuk dalam stopword list maka dilakukan penghapusan dari deskripsi dan dianggap sebagai kata-kata yang mencirikan isi dari suatu dokumen atau kata kunci. Pada penelitian ini menggunakan kamus stopword yang disediakan oleh library dari Node JS yaitu stopwords-iso/stopwords-id yang mendukung kamus stopword berbahasa Indonesia.

Selanjutnya, penelitian ini melakukan proses stemming dengan menggunakan kamus kata dasar dari kata dasar untuk membandingkan dasar dan terkait. Data kata kunci diambil dari kamus online Bahasa Indonesia berjumlah 29.932. Stemming adalah proses mengelompokkan berbagai variasi morfologi suatu kata atau kalimat menjadi satu bentuk dasar (Siswandi, Permana, \& Emarilis, 2021). Tahap terakhir yaitu filter redudansi untuk meningkatkan penghitungan frekuensi kata selama proses pembobotan, diperlukan penyaringan redudansi untuk mencari kata yang sama. Dalam arti tertentu, kata-kata dalam dokumen dibandingkan dengan kamus dalam database. Jika kata ini ditemukan, kata tersebut merupakan sinonim (Sukmana \& Salsabilla, 2018).

Setelah proses text preprocessing, penelitian ini melakukan ekstraksi fitur untuk meminimalisir noise, sehingga akurasi tinggi. Data yang sudah siap diproses itu kemudian dihitun g seberapa banyak kemunculan atau frekuensi kemunculan setiap katanya di dalam dokumen, yang dikenal dengan tahap pembobotan term menggunakann metode TF-IDF. Pembobotan term adalah pembobot untuk setiap kata dengan penggunaan TFIDF (Term Frequency - Inversed Document Frequency) (Gunawan, Pratiwi, \& Pratama, 2018). Proses TF-IDF dengan menghitung bobot dengan mengintegrasikan term frequency (tf) dan inverse document frequency (idf). TF merupakan cara menghitung bobot tiap term dalam tweet. Jumlah dokumen yang mengandung suatu term tertentu dinamakan DF. Dokumen Frekuensi merupakan metode feature selection yang paling sederhana dengan waktu komputasi yang rendah. Inverse Document Frequency (IDF) TF fokus pada term di cuitan, maka IDF focus dengan munculnya term di keseluruhan lokasi tweet dan term yang jarang muncul pada keseluruhan koleksi term dinilai berharga. Term Frequency Inverse Document 
Frequency mencantumkan bobot setelah menghasilkan term dalam tweet kemudian menghitungnya dengan mengintegrasikan tf dengan idf. Sebagaimana ditunjukan pada Persamaan 1.

$$
T F-I D F=T F * I D F=T F * \log (n / d f)
$$

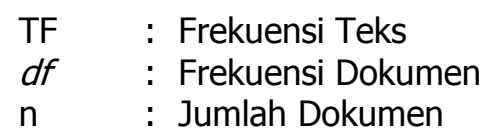

Tahapan pembangunan model mengimplemntasikan algoritma Naïve Bayes, dimana tahap ini untuk mengetahui pola sentiment pada setiap tweet berdasarkan kelasnya sebagaimana diuraikan pada alur algoritma Naïve Bayes:

1. Pembacaan data latih

2. Penjumlahan dan probabilitas, dicari nilai mean untuk data numeric dan standar deviasi setiap parameter seperti ditunjukan pada Persamaan 2.

$$
\mu=\frac{\sum_{i-1}^{n} X i}{n}
$$

$\mu$ : rata-rata hitung (mean)

$x_{i}$ : nilai sampel ke-i

$\mathrm{n}$ : jumlah sampe

3. Menemukan nilai dalam tabel mean, deviasi standar, dan probabilitas

4. Hasil klasifikasi

Nilai probabilitas dibandingkan dengan suatu sampel di kelasnya dan yang lain untuk menemukan kelas. Kemudian dilakukan penentuan kelas yang sesuai sampel dengan perbandingan nilai posterior tiap kelas dan memilih kelas dengan nilai Posterior tertinggi. Probabilitas prior dan teorema bayes sebagaimana ditunjukan pada Persamaan 3 dan Persamaan 4. Pengklasifikasian dengan Naïve Bayes dibagi kedalam 2 proses, yaitu fase learning dan fase testing. Fase learning untuk menghasilkan model yang dijadikan refresnsi dalam mengklasifikasikan sentiment pada fase testing (Rahayu \& Zharfan, 2015).

$$
P(H)=\frac{N j}{N}
$$

$\mathrm{P}(\mathrm{H}) \quad$ : Peluang prior

NJ : Jumlah data pada suatu kelas

$\mathrm{N} \quad$ : Jumlah total data

$$
P(H \mid X)=\frac{P(H / X) \cdot P(H)}{P(X)}
$$

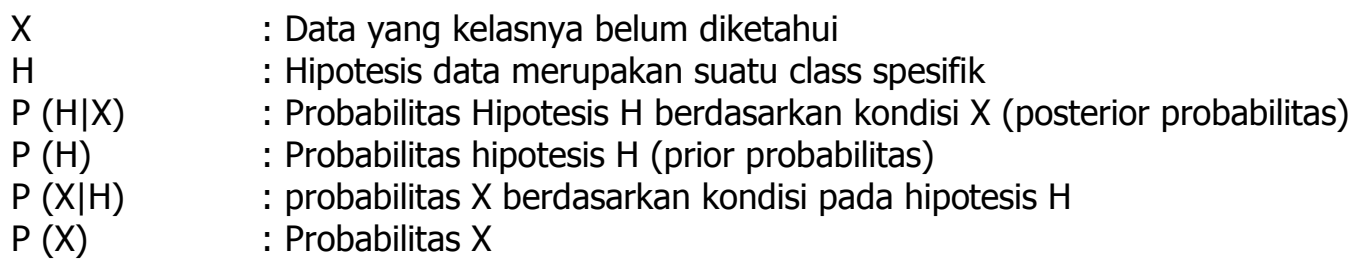

Penelitian ini melakukan evaluasi atau menguji validasi model bertujuan untuk menilai kinerja algoritma dengan menampilkan akurasi, precision dan recall menggunakan confusion matrix. Penggunaan Confusion Matrix untuk menghitung tingkat akurasi, dengan menghitung jumlah prediksi benar dan salah berdasarkan perbandingan data real atau prediksi target (Arini, Wardhani, \& Octaviano, 2020). Pengujian data yang kemudian diprediksi kelas dibandingkan dengan kelas sesungguhnya dari data uji yang disimpan terlebih dahulu. Tahpan selanjutnya dapat direpresentasikan hasils nilai accuration, precision, recall, dan f1- 
score (Imron, 2018). Terdapat beberapa parameter pengujian berdasarkan perbandingan nilai prediksi dan nilai actual yaitu:

1. Accuracy dapat diartikan pengujian dari kedekatan nilai prediksi dengan nilai actual dalam kumpulan data.

$$
\text { Accuracy }=\frac{\text { Nbenar }}{N} \times 100 \%
$$

2. Precision adalah sebuah pengujian melalui perbandingan jumlah informasi yang sesuai diperoleh sistem dengan jumlah seluruh informasi yang terambil oleh system, walaupun tidak sesuai.

$$
\text { Precision }=\frac{T P}{T P+F P}
$$

3. Recall dapat diperoleh dengan membandingkan jumlah informasi relevan yang diperoleh sistem dengan jumlah seluruh informasi relevan yang ada dalam label informasi.

$$
\text { Recall }=\frac{T P}{T P+F N}
$$

\section{HASIL DAN PEMBAHASAN}

\subsection{Seleksi Fitur}

Proses pembobotan penelitian ini menggunakan TF-IDF sebagaimana ditunjukan pada Persamaan 1, dan flowchart yang diilustrasikan pada Gambar 3. Langkah pertama yaitu Menghitung jumlah kemunculan kata, kemudian menghitung jumlah dokumen dan query berisi kata (DF) lalu menghitung IDF menggunakan Persamaan 6 dan menghitung TF-IDF dengan Persamaan 7 dan hasil ditunjukan pada Tabel 1.

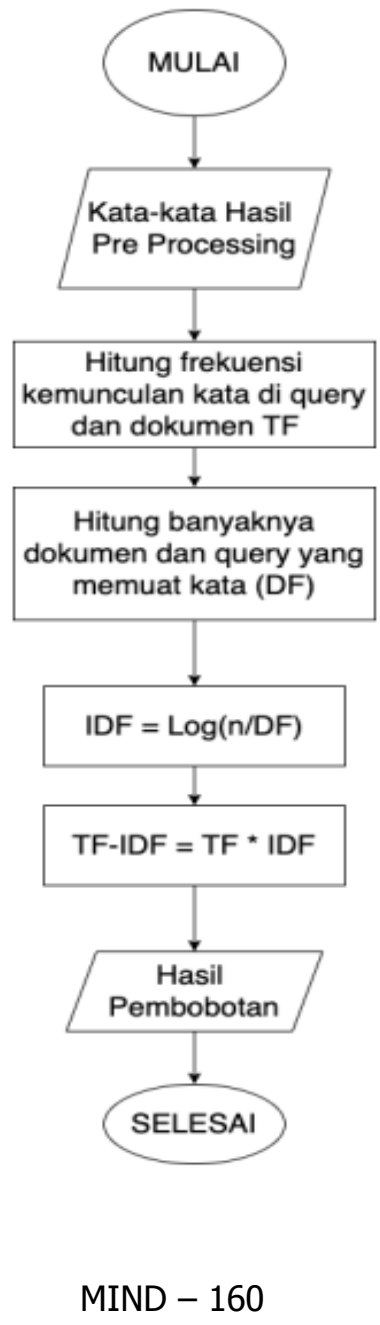


Pemodelan Analisis Sentimen Masyarakat terhadap Adaptasi Kebiasaan Baru (AKB) mengunakan Algoritma Naïve Bayes

Gambar 3. Flowchart Proses Pembobotan Term

Tabel 1. Hasil Perhitungan TF, DF, IDF dan TF-IDF

\begin{tabular}{|c|c|c|c|c|c|c|c|c|c|c|c|c|c|c|c|c|c|c|c|c|}
\hline \multirow[b]{2}{*}{ Kata } & \multicolumn{11}{|c|}{ TF } & \multicolumn{9}{|c|}{ TF-IDF } \\
\hline & $\begin{array}{l}\text { D } \\
\mathbf{1}\end{array}$ & $\begin{array}{l}\text { D } \\
2 \\
\end{array}$ & $\begin{array}{l}\text { D } \\
3\end{array}$ & $\begin{array}{l}\text { D } \\
4 \\
\end{array}$ & $\begin{array}{l}\text { D } \\
5\end{array}$ & $\begin{array}{l}\text { D } \\
6 \\
\end{array}$ & $\begin{array}{l}\text { D } \\
7\end{array}$ & $\begin{array}{l}\text { D } \\
8 \\
\end{array}$ & $\begin{array}{l}\text { D } \\
9 \\
\end{array}$ & DF & IDF & D1 & D2 & D3 & D4 & D5 & D6 & D7 & D8 & D9 \\
\hline selamat & 2 & 0 & 0 & 0 & 0 & 0 & 0 & 0 & 0 & 2 & $\begin{array}{c}0.6532 \\
1251\end{array}$ & $\begin{array}{l}1.306 \\
42503\end{array}$ & 0 & 0 & 0 & 0 & 0 & 0 & 0 & 0 \\
\hline sehat & 1 & 1 & 0 & 1 & 0 & 0 & 0 & 0 & 0 & 3 & $\begin{array}{c}0.4771 \\
2125 \\
\end{array}$ & $\begin{array}{l}0.477 \\
12125 \\
\end{array}$ & $\begin{array}{c}0.4771 \\
2125 \\
\end{array}$ & $\begin{array}{c}0.4771 \\
2125 \\
\end{array}$ & 1 & 0 & 0 & 0 & 0 & 0 \\
\hline rutin & 1 & 0 & 0 & 0 & 0 & 0 & 0 & 0 & 0 & 1 & $\begin{array}{c}0.9542 \\
4251\end{array}$ & $\begin{array}{l}0.954 \\
24251\end{array}$ & 0 & 0 & 0 & 0 & 0 & 0 & 0 & 0 \\
\hline pulih & 0 & 1 & 0 & 0 & 0 & 0 & 0 & 0 & 0 & 1 & $\begin{array}{c}0.9542 \\
4251\end{array}$ & 0 & $\begin{array}{c}0.9542 \\
4251\end{array}$ & 0 & 0 & 0 & 0 & 0 & 0 & 0 \\
\hline protokol & 1 & 0 & 0 & 1 & 0 & 0 & 0 & 0 & 0 & 2 & $\begin{array}{c}0.6532 \\
1251\end{array}$ & $\begin{array}{r}0.653 \\
21251 \\
\end{array}$ & 0 & $\begin{array}{c}0.6532 \\
1251\end{array}$ & 1 & 0 & 0 & 0 & 0 & 0 \\
\hline pandemi & 0 & 1 & 0 & 0 & 0 & 0 & 0 & 0 & 0 & 1 & $\begin{array}{c}0.9542 \\
4251\end{array}$ & 0 & $\begin{array}{c}0.9542 \\
4251\end{array}$ & 0 & 0 & 0 & 0 & 0 & 0 & 0 \\
\hline lindungi & 1 & 0 & 0 & 0 & 0 & 0 & 0 & 0 & 0 & 1 & $\begin{array}{c}0.9542 \\
4251\end{array}$ & $\begin{array}{r}0.954 \\
24251\end{array}$ & 0 & 0 & 0 & 0 & 0 & 0 & 0 & 0 \\
\hline lelah & 0 & 2 & 0 & 0 & 0 & 0 & 0 & 0 & 0 & 2 & $\begin{array}{c}0.6532 \\
1251\end{array}$ & 0 & $\begin{array}{c}1.3064 \\
2503\end{array}$ & 0 & 0 & 0 & 0 & 0 & 0 & 0 \\
\hline kondisi & 0 & 1 & 0 & 0 & 0 & 0 & 0 & 0 & 0 & 1 & $\begin{array}{c}0.9542 \\
4251 \\
\end{array}$ & 0 & $\begin{array}{c}0.9542 \\
4251 \\
\end{array}$ & 0 & 0 & 0 & 0 & 0 & 0 & 0 \\
\hline jaga & 1 & 1 & 0 & 0 & 0 & 0 & 0 & 0 & 0 & 2 & $\begin{array}{c}0.6532 \\
1251\end{array}$ & $\begin{array}{l}0.653 \\
21251\end{array}$ & $\begin{array}{c}0.6532 \\
1251\end{array}$ & 0 & 0 & 0 & 0 & 0 & 0 & 0 \\
\hline covid & 1 & 0 & 1 & 0 & 0 & 0 & 0 & 0 & 0 & 2 & $\begin{array}{c}0.6532 \\
1251\end{array}$ & $\begin{array}{r}0.653 \\
21251 \\
\end{array}$ & 0 & $\begin{array}{c}0.6532 \\
1251\end{array}$ & 0 & 0 & 0 & 0 & 0 & 0 \\
\hline ancam & 1 & 0 & 0 & 0 & & 0 & 0 & 0 & 0 & 1 & $\begin{array}{c}0.9542 \\
4251\end{array}$ & $\begin{array}{r}0.954 \\
24251 \\
\end{array}$ & 0 & 0 & 0 & & 0 & 0 & 0 & 0 \\
\hline aktivitas & 1 & 0 & 0 & 0 & 0 & 0 & 0 & 0 & 0 & 1 & $\begin{array}{c}0.9542 \\
4251 \\
\end{array}$ & $\begin{array}{r}0.954 \\
24251 \\
\end{array}$ & 0 & 0 & 0 & 0 & 0 & 0 & 0 & 0 \\
\hline adaptasi & 1 & 0 & 0 & 0 & 1 & 1 & 0 & 0 & 0 & 3 & $\begin{array}{c}0.4771 \\
2125\end{array}$ & $\begin{array}{l}0.477 \\
12125\end{array}$ & 0 & 0 & $\begin{array}{c}0.4 \\
771 \\
212 \\
6 \\
\end{array}$ & $\begin{array}{c}0.4 \\
771 \\
212 \\
7 \\
\end{array}$ & 0 & 0 & 0 & 0 \\
\hline
\end{tabular}

Berdasarkan Tabel 1, diilustrasikan sampel 9 dokumen yang berasal dari 9 tweet dari ribuan data yang sudah dicrawling untuk dihitung TF, DF, IDF dan TF-IDF. Tahapan pembobotan tern ini merupakan transformasi data dari data teks ke dalam sebuah matriks yang berisi numerik yang kemudian data dapat diolah dan diterapkan ke dalam model klasifikasi.

\subsection{Pemodelan Naïve Bayes Classification}

Mengasumsikan bahwa efek fitur tertentu dalam kelas tidak bergantung pada fitur lainnya merupakan Naïve Bayes Classification. Asumsi ini menyederhanakan komputasi yang disebut kebebasan bersyarat kelas. Langkah pertama adalah memahami dan mengidentifikasi fitur dan label potensial. Klasifikasi ini memiliki dua tahap, tahap pembelajaran dan tahap evaluasi. Ketepatan analisis algoritma benar jika menghasilkan luaran yang benar jika menerima masukan sesuai dengan definisinya, dan dapat diterminasi (berakhir) (Sim, 2013).

Proses training pada penelitian ini seperti diilustrasikan dalam Tabel 2, dengan pengklasifikasi melatih modelnya pada dataset tertentu sebagaimana dihasilkan probabilitas yang merupakan hasil perhitungan setiap term yang ditambahkan dan dicari nilai paling tinggi dan dijadikan kelas untuk term seperti pada Tabel 3. Tahapan ini data telah berbobot seperti contoh pada Tabel 3 sebagai data latih sebagai referensi pembentukan model klasifikasi, kemudian pencarian nilai probabilitas kategori dan peluang setiap kata dari data latih. Untuk mengakumulasi nilai peluar kategori dan kata dengan mengimplementasikan Persamaan 2 pada seriap term untuk setiap kelas dari data latih. Jumlah seluruh term dalam data latih yang dipakai pada perhitungan sebanyak 9 term dimana 3 term adalah positif, 4 
term adalah negatif dan 2 term adalah netral. Data hasil pembobotan term pada Tabel 3 dilakukan perhitungan probabilitas setiap term. Sebagai contoh kata "selamat" pada Tabel 3 berdasarkan perhitungan probabilitas menggunakan Persamaan 3 dan 4.

Tabel 2. Contoh Data Training

\begin{tabular}{|c|c|c|c|}
\hline Kode & Sebelum Pra-Proses & Setelah Pra-Proses & Kelas \\
\hline D1 & $\begin{array}{l}\text { @PT_Transjakarta: Selamat Pagi, selamat } \\
\text { beraktivitas. Adaptasi Kebiasaan Baru menjadi } \\
\text { rutinitas keseharian dengan menjaga protokol } \\
\text { kesehatan dimulai dari diri sendiri untuk saling } \\
\text { melindungi dari ancaman Covid-19. }\end{array}$ & $\begin{array}{l}\text { selamat selamat } \\
\text { aktivitas adaptasi rutin } \\
\text { jaga protokol sehat } \\
\text { lindung ancam covid }\end{array}$ & Positif \\
\hline D2 & $\begin{array}{l}\text { @tia_alzahira: Ketika ditanya lelah nggak sih } \\
\text { sama pandemi yang nggak terasa udah setahun } \\
\text { berlalu? }\end{array}$ & $\begin{array}{l}\text { lelah pandemi } \\
\text { lelah kondisi pulih } \\
\text { wajib disiplin protokol } \\
\text { jaga sayang }\end{array}$ & Negatif \\
\hline D3 & $\begin{array}{l}\text { @Cahyailahi6: Pemerintah Indonesia terima 83,9 } \\
\text { juta dosis vaksin covid-19 }\end{array}$ & dosis vaksin covid & Netral \\
\hline D4 & $\begin{array}{l}\text { @Dien_Drew1: Iya lagi naik"lagi nih kak .gmn ya } \\
\text { dilarang mudik mngkn taun lalu gak mudik .sdh } \\
\text { lelah mereka kak dgn aturan"yg gak jelas gini }\end{array}$ & $\begin{array}{l}\text { larang mudik mudik } \\
\text { lelah aturan }\end{array}$ & $?$ \\
\hline
\end{tabular}

\section{Probabilitas kata "selamat" pada Data Training (Positif) berdasarkan Tabel 3}

$p($ selamat"|"pos" $)=\frac{\text { "selamat"|"pos" + } 1}{(" p o s ")+\mid \text { kosakata } \mid}=\left(\frac{1.306+1}{33+46}\right)=0,0292$

$p($ selamat"|"neg" $)=\frac{\text { "selamat"|"neg" + } 1}{(\text { "neg" })+\mid \text { kosakata } \mid}=\left(\frac{0+1}{19+46}\right)=0,0154$

$p\left(\right.$ "selamat"|"net") $=\frac{\text { "selamat"|"net" }+1}{(\text { "net") }+\mid \text { kosakata } \mid}=\left(\frac{0+1}{23+46}\right)=0,0145$

Maka kata selamat mendapatkan nilai positif yang lebih besar dibandingkan dengan term lainnya. Hasil probabilitas kata lainnya terlihat pada Tabel 3 sebagai luarannya, probabilitas diperoleh dari nilai yang paling tinggi dan dijadikan kelas untuk term tersebut.

Tabel 3. Perhitungan Probablitas Kata 
Pemodelan Analisis Sentimen Masyarakat terhadap Adaptasi Kebiasaan Baru (AKB) mengunakan Algoritma Naïve Bayes

\begin{tabular}{|c|c|c|c|c|c|c|}
\hline \multirow[t]{2}{*}{ Kata } & \multicolumn{3}{|c|}{$\begin{array}{l}\text { Jumlah frekuensi } \\
\left(n_{k}, \text { pos/neg/net }\right)\end{array}$} & \multicolumn{3}{|c|}{$\begin{array}{c}\text { Probabilitas Kata } \\
p\left(w_{k} \mid \text { pos/neg/net }\right)\end{array}$} \\
\hline & pos & neg & net & pos & neg & net \\
\hline & 1,3064250 & & & 0,020105 & 0,0153846 & 0,014 \\
\hline selamat & 3 & 0 & 0 & 25 & 2 & 49278 \\
\hline & 0,0542425 & & & 0,024737 & 0,0153846 & 0,014 \\
\hline aktivitas & 1 & 0 & 0 & 25 & 2 & 49275 \\
\hline & 1,4313637 & & & 0,030776 & 0,0153846 & 0,014 \\
\hline adaptasi & 6 & 0 & 0 & 76 & 2 & 49275 \\
\hline & 0,9542425 & & & 0,024737 & 0,0153846 & 0,014 \\
\hline rutin & 1 & 0 & 0 & 25 & 2 & 49275 \\
\hline & 0,6532125 & & 0,653212 & 0,020926 & 0,0153846 & 0,023 \\
\hline jaga & 1 & 0 & 51 & 74 & 2 & 9596 \\
\hline & 1,3064250 & & & 0,029195 & 0,0153846 & 0,014 \\
\hline protokol & 3 & 0 & 0 & 25 & 2 & 49275 \\
\hline & 0,9542425 & & 0,477121 & 0,024737 & 0,0153846 & 0,021 \\
\hline sehat & 1 & 0 & 25 & 25 & 2 & 40755 \\
\hline
\end{tabular}

\begin{tabular}{|c|c|c|c|c|c|c|}
\hline \multirow[t]{2}{*}{ Kata } & \multicolumn{3}{|c|}{$\begin{array}{l}\text { Jumlah frekuensi } \\
\left(n_{k}, \text { pos/neg/net }\right)\end{array}$} & \multicolumn{3}{|c|}{$\begin{array}{c}\text { Probabilitas Kata } \\
p\left(w_{k} \mid \text { pos/neg/net }\right)\end{array}$} \\
\hline & pos & neg & net & pos & neg & net \\
\hline & 0,9542425 & & & 0,024737 & 0,0153846 & 0,014 \\
\hline lindungi & 1 & 0 & 0 & 25 & 2 & 49275 \\
\hline & 0,9542425 & & & 0,024737 & 0,0153846 & 0,014 \\
\hline ancam & 1 & 0 & 0 & 25 & 2 & 49275 \\
\hline & 0,6532125 & & 0,653212 & 0,020926 & 0,0153846 & 0,023 \\
\hline covid & 1 & 0 & 51 & 74 & 2 & 9596 \\
\hline & & & 1,306425 & 0,012658 & 0,0153846 & 0,033 \\
\hline lelah & 0 & 0 & 03 & 23 & 2 & 42645 \\
\hline & & & 0,954242 & 0,012658 & 0,0153846 & 0,028 \\
\hline pandemi & 0 & 0 & 51 & 23 & 2 & 32236 \\
\hline & & & 0,954242 & 0,012658 & 0,0153846 & 0,028 \\
\hline kondisi & 0 & 0 & 51 & 23 & 2 & 32236 \\
\hline & & & 0,954242 & 0,012658 & 0,0153846 & 0,028 \\
\hline pulih & 0 & 0 & 51 & 23 & 2 & 32236 \\
\hline & & & 0,954242 & 0,012658 & 0,0153846 & 0,028 \\
\hline wajib & 0 & 0 & 51 & 23 & 2 & 32236 \\
\hline
\end{tabular}

Langkah-langkah pada proses testing menyerupai dengan alur proses training, yaitu:

Proses 1: Pengujian memberikan data uji pada model dalam pelatihan. Contoh perhitungan pada proses 2 menggunakan D4.

Proses 2: Setelah proses seleksi data testing dihitung nilai probabilitas tiap kata dalam data testing dengan hasil probabilitas term dari data training.

Perhitungan probabilitas dilakukan dengan Persamaan 1. Probabilitas Data Testing (Positif) berdasarkan Tabel 1, menghasilkan 0.012 untuk peluang kata "larang", "mudik", "lelah" pada kelas positif. Sedangkan pada kelas negative mengasilkan nilai berturut-turut yaitu $0.0147,0.035,0.0154$.

p ("larang"|"pos") $=\left(\frac{0+1}{33+46}\right)=0,012$

$p\left(\right.$ mudik"|"pos") $=\left(\frac{0+1}{33+46}\right)=0,012$

$p("$ lelah"|"pos" $)=\left(\frac{0+1}{33+46}\right)=0,012$

Probabilitas Data Testing (Negatif) berdasarkan Tabel 1

$p\left(\right.$ "larang"|"neg") $=\left(\frac{-0,4575749+1}{19+46}\right)=0,0147$
$p("$ mudik"|"neg" $)=\left(\frac{-0,4575749+1}{19+46}\right)=0,035$
$p($ "lelah"|"neg" $)=\left(\frac{0+1}{19+46}\right)=0,0154$

Probabilitas Data Testing (Netral) berdasarkan Tabel 1

p("larang"|"net") $=\left(\frac{-0,4575749+1}{23+46}\right)=0,0145$

$p\left(\right.$ "mudik"|"net") $=\left(\frac{-0,4575749+1}{23+46}\right)=0,0145$

$p\left(\right.$ "lelah"|"net") $=\left(\frac{0+1}{23+46}\right)=0,0334$ 


\section{Proses 3: Menghitung probabilitas kategori dengan Persamaan 2}

$\mathrm{P}($ testing $\mid$ pos $)=\mathrm{P}($ pos $) \times \mathrm{P}$ (larang $\mid$ pos $) \times \mathrm{P}$ (mudik $\mid$ pos $) \times \mathrm{P}$ (lelah $\mid$ pos $)$

$P($ testing $\mid$ pos $)=0,33 \times 0,0147 \times 0,034 \times 0,0154=2,53998 \mathrm{E}-06$

$\mathrm{P}($ testing $\mid$ neg $)=\mathrm{P}($ neg $) \times \mathrm{P}$ (larang $\mid$ neg $) \times \mathrm{P}($ mudik $\mid$ neg $) \times \mathrm{P}$ (lelah $\mid$ neg $)$

$P($ testing $\mid$ neg $)=0,44 \times 0,0147 \times 0,035 \times 0,0154=3,48625 \mathrm{E}-06$

$\mathrm{P}($ testing $\mid$ net $)=\mathrm{P}$ (net) $\times \mathrm{P}$ (larang $\mid$ net $) \times \mathrm{P}$ (mudik $\mid$ net $) \times \mathrm{P}$ (lelah $\mid$ net $)$

$P($ testing $\mid$ net $)=0,22 \times 0,0145 \times 0,0145 \times 0,0334=1,54492 \mathrm{E}-06$

Nilai probabilitas tertinggi kategori negatif sebesar 3, 48625E-06, sehingga D4 dapat dikategorikan kedalam kelas Negatif. Sebagai contoh kata "selamat" pada Tabel 2 menunjukkan perhitungan nilai positif yang lebih besar dibandingkan dengan term lainnya. Hasil probabilitas kata lainnya terlihat pada Tabel 3 di bawah yang merupakan luaran perhitungan setiap term yang sudah ditambahkan, kemudian dicari nilai yang terbesar dan digunakan sebagai kelas untuk term tersebut.

\section{3 Antarmuka sistem}

Penelitian ini menghasilkan antarmuka berbasis Web yang dinamis, dengan menyajikan informasi tweet, score, klasifikasi sentimen yang dilengkapi summary berupa grafik. Tampilan antarmuka Web Twitter Sentiment Analysis ditunjukan pada Gambar 4.

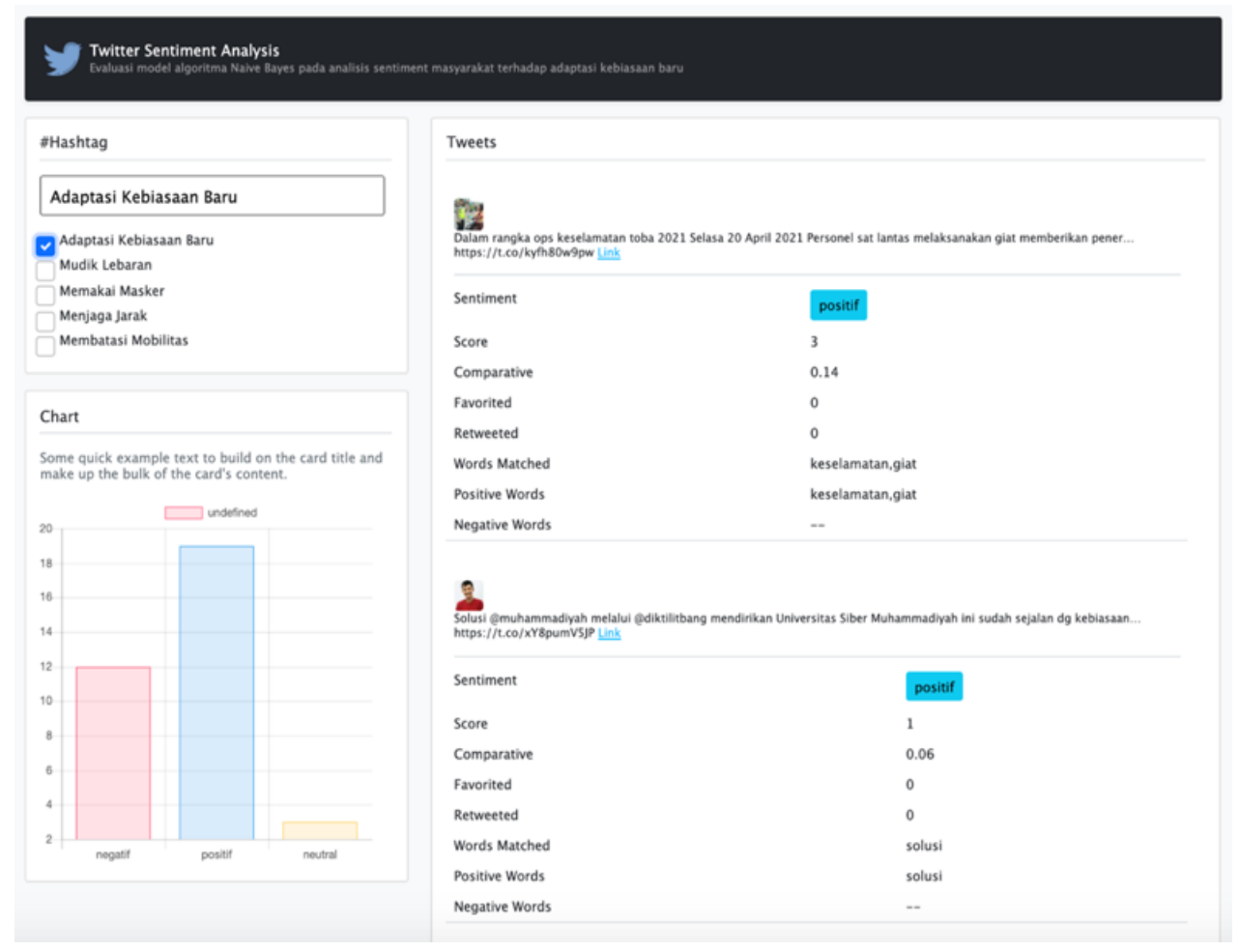

Gambar 4. Tampilan Antarmuka

Pengguna dapat melakukan proses pemilihan \#hashtag atau topik yang ingin dilakukan analisa tweet. Tweet berubah setelah topik di pilih. Setelah pengguna memilih topik atau hashtag yang ingin dianalisa, Data tweet dari twitter berada pada tab tweets. 
Pemodelan Analisis Sentimen Masyarakat terhadap Adaptasi Kebiasaan Baru (AKB) mengunakan Algoritma Naïve Bayes

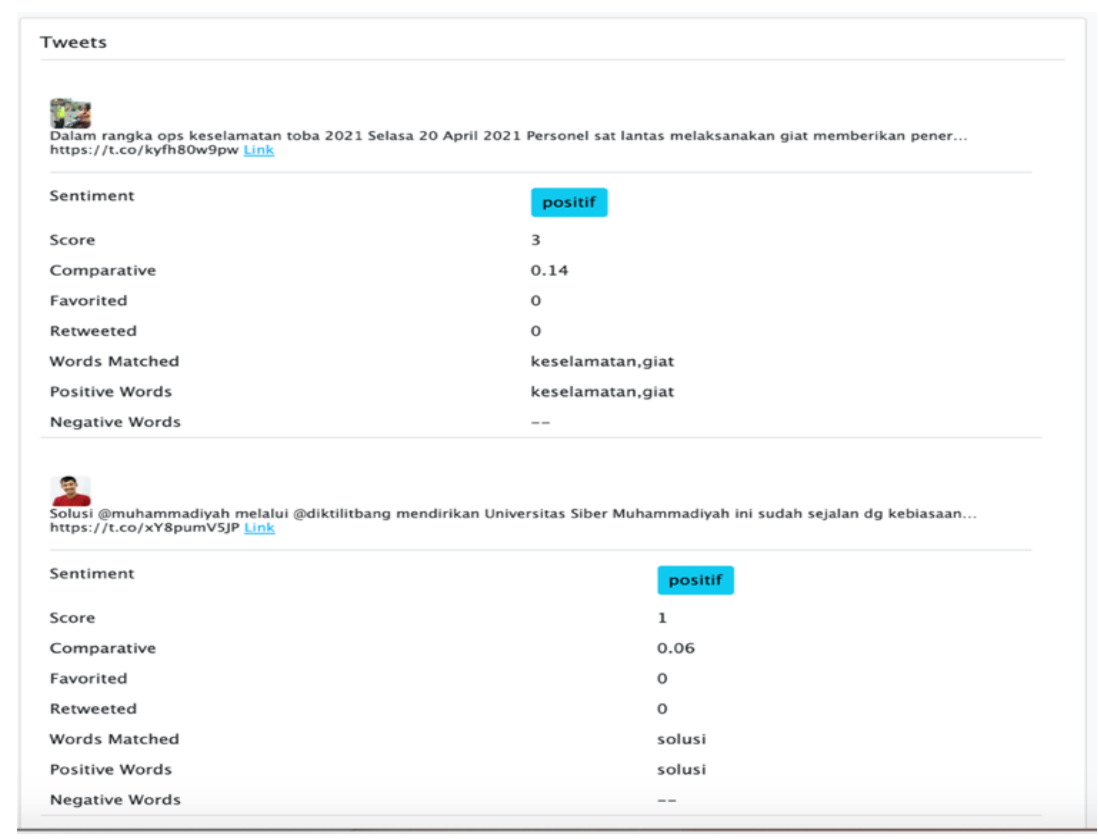

\section{Evaluasi Model menggunakan Confusion Matrix}

Gambar 5. Tab Tweets

Pada tahap evaluasi, pengklasifikasi menguji kinerja pengklasifikasi. Kinerja dievaluasi berdasarkan parameter seperti acuration, precision dan recall.

\subsection{Pengujian Confusion Matrix}

Pengujian dilakukan dengan menggunakan 70 data berlabel. Parameter yang dihitung dalam pengujian ini yaitu accuration, precision, recall. Ketiga parameter tersebut dihitung dengan menggunakan metode Confusion Matrix. Metode ini umumnya digunakan untuk melakukan perhitungan keakurasian pada data mining. Hasil pengujian akurasi klasifikasi tweets dengan menggunakan 20 data training dan 50 data uji.

Tabel 4. Pengujian dengan Confusion Matrix

\begin{tabular}{|c|c|c|c|c|}
\hline \multirow{4}{*}{$\begin{array}{l}\text { Predicted } \\
\text { Class }\end{array}$} & & \multicolumn{3}{|c|}{ Actual Class } \\
\hline & & Positif & Negatif & Netral \\
\hline & Positif & 8 & 2 & 1 \\
\hline & Negatif & 1 & 15 & 4 \\
\hline & Netral & 0 & 4 & 15 \\
\hline \multicolumn{2}{|c|}{ Total Kelas } & 9 & 21 & 20 \\
\hline
\end{tabular}

Penelitian ini menghasilkan akurasi yang lebih tinggi meskipun tanpa seleksi fitur yaitu sebagaimana terlampir pada Tabel 5 melalui Persamaan 5, Persamaan 6 dan Persamaan 7 untuk menghasilkan performance algoritma.

Tabel 5. Hasil Pengujian dengan confussion matrix tanpa seleksi fitur

\begin{tabular}{|l|l|l|l|l|}
\hline Class & N(truth) & N(classified) & Precision & Recall \\
\hline Positif & 9 & 11 & $70,127 \%$ & $79,84 \%$ \\
\hline Negatif & 21 & 20 & $71.7 \%$ & $70,12 \%$ \\
\hline Netral & 20 & 19 & $75,247 \%$ & $72.58 \%$ \\
\hline
\end{tabular}

Tabel 6. Hasil Pengujian dengan confussion matrix dengan seleksi fitur 


\begin{tabular}{|l|l|l|l|l|}
\hline Class & N(truth) & N(classified) & Precision & Recall \\
\hline Positif & 9 & 11 & $72,727 \%$ & $88,88 \%$ \\
\hline Negatif & 21 & 20 & $75 \%$ & $71,4 \%$ \\
\hline Netral & 20 & 19 & $78,947 \%$ & $75 \%$ \\
\hline
\end{tabular}

Hasil pengujian menunjukan tingkat accuracy sebesar $63.21 \%$ tentang analisis sentimen opini publik mengenai covid-19 pada twitter menggunakan metode naïve bayes tanpa menggunakan seleksi fitur (Syarifuddin, 2020). Pada penelitian ini menghasilkan akurasi yang lebih tinggi meskipun tanpa seleksi fitur yaitu sebagaimana terlampir pada Tabel 5.

Berdasarkan pengujian akurasi menggunakan Persamaan 5, Persamaan 6 dan Persamaan 7 dimana hasil akurasi klasifikasi tweets dari sistem analisis sentimen dengan menggunakan Naïve Bayes classifier yang ditambah dengan seleksi fitur sebesar $76 \%$ dengan accuracy positif sebesar $72,727 \%$, accuracy negatif sebesar $75 \%$ dan accuracy netral sebesar 78,947\%. Penelitian sebelumnya sebagaimana ditunjukan pada Tabel 5, menghasilkan akurasi yang lebih rendah dibandingan dengan Tabel 6 yang sudah menggunakan seleksi fitur sebelum pemodelan dilakukan.

\section{KESIMPULAN}

Simpulan peneliian menunjukan bahwa dengan penambahan seleksi fitur dapat meningkatkan nilai akurasi sebanyak $5 \%$ yaitu $78,947 \%$ dibandingkan tanpa menggunaka seleksi fitur. Pengaruh akurasi dalam metode Naïve Bayes bergantung kepada dataset, praproses dan optimasi metode sebelum penggunaan algoritma atau metode untuk klaifikasi. Pada dataset yang digunakan untuk training masih belum terlalu bervariasi, namun sudah menunjukkan hasil pembelajaran yang signifikan antara klasifikasi tanpa dan dengan menggunakan fitur seleksi. Dimana akurasi tertinggi pada klasifikasi Naïve Bayes tanpa seleksi fitur sebesar $75,247 \%$ sebgaimana ditunjukan padanTabel 5 sedangkan klasifikasi dengan penambahan seleksi fitur ditunjukan pada Tabel 6 mencapai nilai sebesar 78,947\% pada kelas netral. Penelitian ini lebih baik hasil performance model klasifikasinya jika dibandingkan dengan penelitian sebelumnya yang menghasilkan accuracy sebesar $63.21 \%$ tentang analisis sentimen mengenai covid-19 pada twitter dengan mengimplementasikan naïve bayes (Syarifuddin, 2020). Perningkatan sebesar $15 \%$ antara klasifikasi dengan penambahan fitur seleksi sebagaimana terlampir pada Persamaan 2.

\section{UCAPAN TERIMA KASIH}

Penulis sampaikan ucapkan terimakasih kepada seluruh pihak, khususnya civitas akademik STMIK Bandung atas kerjasama dan bantuan baik secara langsung maupun tidak langsung sehingga penelitian ini dapat dirampungkan, meskipun masih harus dikembangkan demi peningkatan kualitas. Penulis juga sampaikan ucapat terimkasih yang mendalam kepada keluarga dan rekan yang selalu memberi semangat untuk penyelesaian penelitian ini, dengan harapan dapat menjadi referensi untuk para peneliti yang berminat mengembangkan penelitian ini.

\section{DAFTAR RUJUKAN}

MIND - 166 
Pemodelan Analisis Sentimen Masyarakat terhadap Adaptasi Kebiasaan Baru (AKB) mengunakan Algoritma Naïve Bayes

Arini, Wardhani, L. K., \& Octaviano, D. (2020). Perbandingan Seleksi Fitur Term Frequency \& Tri-Gram Character menggunakan Algoritma Naïve Bayes Classifier pada Tweet Hashtag \#2019gantipresiden. KILAT, 103 - 114.

Gunawan, B., Pratiwi, H. S., \& Pratama, E. E. (2018). Sistem Analisis Sentimen pada Ulasan Produk menggunakan Naive Bayes. Jurnal Edukasi dan Penelitian Informatika, 113118.

Hermanto, \& Noviriandini, A. (2021). ANALISA SENTIMEN TERHADAP BELAJAR ONLINE PADA MASA COVID-19. Jurnal Informatika Kaputama (JIK), 129-13.

Imron, A. (2018). Analisis Sentimen terhadap Tempat Wisata di Kabupaten Rembang menggunakan Metode Naive Bayes Classifier. Yogyakarta: Universitas islam Indonesia.

Larose, D. T. (2014). Discovering Knowledge in Data: An Introduction to Data Mining. John Willey \& Sons, Inc.

Liu, B. (2012). Sentiment Analysis and Opinion Mining. Chicago: Morgan \& Claypool Publisher Retrieved from. Retrieved from Chicago:.

Mubaroka, M. S., Adiwijayab, \& Aldhi, M. D. (2017). Aspect-based sentiment analysis to review products using Naïve Bayes. International Conference on Mathematics: Pure, Applied and Computation (pp. 1-8). Cambridge: AIP Publishing.

Rahayu, M. I., \& Zharfan, F. T. (2015). Analisis Sentimen Laporan Perkembangan Anak Didik Taman Kanak. Jurnal Teknologi Informasi dan Komunikasi, 30-36.

Ratino, Hafidz, N., Anggraeni, S., \& Gata, W. (2020). Sentimen Analisis Informasi Covid-19 menggunakan Support Vector Machine dan Naïve Bayes. Jurnal JUPITER, 01-11.

Ratnawati, F. (2018). Implementasi Algoritma Naive Bayes Terhadap Analisis Sentimen Opini Film Pada Twitter. Jurnal Inovtek Polbeng - Seri Informatika, 51-59.

Saleh, A. (2015, Desember 23). Klasifikasi Gejala Depresi Pada Manusia dengan Metode Naïve Bayes menggunakan Java. Retrieved from Digital Library STMIK AKAKOM: http://eprints.akakom.ac.id/id/eprint/452

Sim, A. X. (2013, July 01). Pengenalan Desain dan Analisis Algoritma. Retrieved from www.dev.bertzzie.com: http://dev.bertzzie.com/knowledge/analisis-algoritma/ PengenalanDesaindanAnalisisAlgoritma.html\#algoritma-yang-baik

Siswandi, A., Permana, A. Y., \& Emarilis, A. (2021). Stemming Analysis Indonesian Language News Text with Porter. Journal of Physics: Conference Series, 01-07.

Sukmana, R. N., \& Salsabilla, Z. S. (2018). Filter Bahasa Kasar menggunakan Algoritma Naïve Bayes. Jurnal Teknologi Informasi dan Komunikasi, 1-5. 
Syarifuddin, M. (2020). Analisis Sentimen Opini Publik Mengenai Covid-19 Pada Twitter Menggunakan Metode Naïve Bayes Dan Knn. Inti Nusa Mandiri, 23-28.

Yuliyanti, S., \& Rizky. (2020). Implementasi Algoritma Rabin Karp untuk Mendeteksi Kemiripan Dokumen STMIK Bandung. Bangkit Indonesia, 1 -6.

Yuliyanti, S., Djatna, T., \& Sukoco, H. (2017). Sentiment Mining of Community Development Program Evaluation Based on Social Media. TELKOMNIKA, 1858 - 1864. 